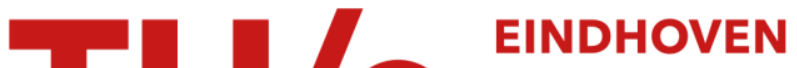 UNIVERSITY OF TECHNOLOGY
}

\section{The future of purchasing and supply management research : about relevance and rigor}

Citation for published version (APA):

Weele, van, A. J., \& Raaij, van, E. M. (2014). The future of purchasing and supply management research : about relevance and rigor. Journal of Supply Chain Management, 50(1), 56-72. https://doi.org/10.1111/jscm.12042

DOI:

10.1111/jscm.12042

Document status and date:

Published: 01/01/2014

Document Version:

Publisher's PDF, also known as Version of Record (includes final page, issue and volume numbers)

Please check the document version of this publication:

- A submitted manuscript is the version of the article upon submission and before peer-review. There can be important differences between the submitted version and the official published version of record. People interested in the research are advised to contact the author for the final version of the publication, or visit the $\mathrm{DOI}$ to the publisher's website.

- The final author version and the galley proof are versions of the publication after peer review.

- The final published version features the final layout of the paper including the volume, issue and page numbers.

Link to publication

\section{General rights}

Copyright and moral rights for the publications made accessible in the public portal are retained by the authors and/or other copyright owners and it is a condition of accessing publications that users recognise and abide by the legal requirements associated with these rights.

- Users may download and print one copy of any publication from the public portal for the purpose of private study or research.

- You may not further distribute the material or use it for any profit-making activity or commercial gain

- You may freely distribute the URL identifying the publication in the public portal.

If the publication is distributed under the terms of Article $25 \mathrm{fa}$ of the Dutch Copyright Act, indicated by the "Taverne" license above, please follow below link for the End User Agreement:

www.tue.nl/taverne

Take down policy

If you believe that this document breaches copyright please contact us at:

openaccess@tue.nl

providing details and we will investigate your claim. 


\title{
THE FUTURE OF PURCHASING AND SUPPLY MANAGEMENT RESEARCH: ABOUT RELEVANCE AND RIGOR
}

\author{
ARJAN J. VAN WEELE \\ Eindhoven University of Technology \\ ERIK M. VAN RAAIJ \\ Erasmus University
}

\begin{abstract}
The Journal of Supply Chain Management (JSCM) is a hallmark in the academic field of operations and supply chain management. During the past 50 years, it has contributed substantially to the recognition and adoption of purchasing and supply management (PSM) as an academic and strategic business domain. Having been invited by the JSCM editors to provide some ideas on the future directions of PSM research, the authors discuss what can be done to further increase both its relevance and rigor. Rigor and relevance in academic research are interconnected. To improve its relevance, the authors argue that future PSM research should better reflect the strategic priorities raised in the contemporary strategic management literature. Next, future PSM research should be much better embedded in a limited number of management theories. Here, stakeholder theory, network theory, the resource-based view of the firm, dynamic capabilities theory, and the relational view could be considered as interesting candidates. Rigor is connected with robustness of academic research designs and projects. To foster its rigor, future PSM research should allow for an increase in the number of replication studies, longitudinal studies, and meta-analytical studies. Future PSM research designs should reflect a careful distinction between informants and respondents and a careful sample selection. When discussing the results of quantitative studies, future PSM research should report on effect sizes and confidence intervals, rather than $p$-values. Adoption of these ideas would have some important implications for both the academic PSM community and academic journal editors.
\end{abstract}

Keywords: purchasing; supply management

\section{INTRODUCTION}

This article addresses the relevance and rigor of academic research in purchasing and supply management (PSM). We discuss relevance in light of the strategic role of purchasing. First, we provide a demarcation of the PSM domain. Next, we present several findings related to the role and importance of this domain in

Acknowledgments: The authors want to extend their gratitude to Mirjam Kibbeling for her permission to use part of her work for our introductory section and Björn Axelsson, Regien Sumo,

Kristine van Tubergen, and Marijn van Weele for their comments on earlier versions of this paper. mainstream strategic management literature. Then, we present an overview of contemporary academic research in purchasing. We demonstrate that PSM has made considerable progress in terms of academic contributions. However, these contributions do not necessarily reflect strategic business issues and concepts. We explore why this situation exists and whether this situation should be changed - and if so, what routes for future research will be available. An important topic, when addressing its relevance, is purchasing and supply research rigor. Various shortcomings in contemporary academic PSM research are discussed. Based upon our discussion, we propose some avenues to improve both PSM research relevance and rigor to 
the benefit of business practitioners, researchers, and editors of academic journals.

\section{PSM: DEMARCATION OF THE FIELD ${ }^{1}$}

PSM is the discipline that is concerned with the management of external resources-goods, services, capabilities, and knowledge - that are necessary for running, maintaining, and managing the primary and support processes of a firm at the most favorable conditions (Van Weele, 2010). Early references to the function go as far back as 1832, and times of difficult supply, such as wars and economic recessions, have helped to establish PSM as a management discipline (Leenders \& Fearon, 2008). Accordingly, the economic recession and supply disruptions of the 1970s put the management of external resources high on the agenda of firms (Kraljic, 1983; Monczka, Handfield, Guinipero, Patterson, \& Waters, 2010). This was also the time that transaction cost economics (TCE) emphasized cost efficiency in decisions about the boundary of the firm and the governance of supplier relationships (Williamson, 1981, 1991). Influenced by such developments, PSM has traditionally had a strong focus on cost reduction, through excellent negotiating tactics and competitive contracting. This cost focus still holds today for many researchers and practitioners, many of whom argue that PSM's added value predominantly lies in cost reduction (Anderson, Thomson, \& Wynstra, 2000; Chen, Paulraj, \& Lado, 2004; González-Benito, 2007).

Due to the increased outsourcing of business activities, PSM has developed into a functional domain of strategic relevance (Carr \& Pearson, 1999; Carter, Monczka, Slaight, \& Swan, 2000; Ellram \& Carr, 1994; Gadde \& Håkansson, 1994; Ogden, Petersen, Carter, \& Monczka, 2005). As suppliers gradually became more important for the competitive positioning of the firm, research in the field examined topics such as supplier relationship management (Gelderman, 2003), collaborative networks (Holmen, Pedersen, \& Jansen, 2007; Joshi, 2009; Spekman \& Carraway, 2006), and early supplier involvement in new product development (Choi, Wu, Ellram, \& Koka, 2002; Van Echtelt, 2004; Wynstra, 1998). The term "strategic purchasing" emerged in the literature (Ellram \& Carr, 1994), but developed into a concept with a strong focus on the integration of the PSM function with other functional domains within the firm and the alignment of purchasing and supply objectives with corporate objectives (Carr \& Pearson, 1999; Wolf, 2005). The strategic positioning of the discipline appears to focus more on the value-added

\footnotetext{
${ }^{1}$ Original text by Kibbeling $(2010,17-20)$ was edited by the authors with permission.
}

of the "purchasing function" than the value-added of suppliers. The current research and literature remain inconclusive about the nature of the contribution firms may want to extract from their suppliers. This is why the dominant focus of the purchasing and supply domain still is on purchasing's "bottom line" impact through cost savings, quality improvement, and technology development (Trent \& Monczka, 1998). The question of how firms could or should create customer and shared value (Porter \& Kramer, 2006) using their supplier networks receives far less attention.

Supply chain management (SCM) involves a broader perspective than PSM. SCM is the part of the operations management discipline that examines three or more organizations involved in the upstream and downstream flows of products, services, finances, and/or information from a source to a customer. SCM typically focuses on the coordination of business functions within and across organizations in a supply chain, for the purposes of improving the long-term performance of the individual organizations and the supply chain as a whole (Giunipero, Hooker, Joseph-Matthews, Yoon, \& Brudvig, 2008; Mentzer et al., 2001). SCM research addresses topics such as the bullwhip effect (Lee, Padmanabhan, \& Whang, 1997), supply chain capacity, sourcing decisions, planning, and scheduling (Kouvelis, Chambers, \& Wang, 2006). Traditionally, SCM focuses on optimizing goods and materials flows, the information required for this, and selecting partners on strategic fit to facilitate an efficient goods flow (Chen \& Paulraj, 2004; Mentzer, Min, \& Zacharia, 2000). PSM, as a more focused discipline, carries prime responsibility for interaction with the upstream supply chain (Schoenherr et al., 2012), but should fulfill this responsibility with the needs of internal functions as well as the downstream customer(s) interests and demands in mind.

Today, SCM research has started to cover a broader spectrum of research topics and includes, among others, product and service development, quality management, logistics, information systems, and human resources management to reflect the value of a firm's capabilities in both manufacturing and service supply chains (Ellram, Tate, \& Billington, 2004; Giunipero et al., 2008; Sampson \& Spring, 2012). Service encounters within and between firms have become key for business operations and typically involve knowledge sharing, competencies, and a mutual understanding between buyer and supplier to enable optimal business-to-business service and goods exchange (Rosenzweig \& Roth, 2007; Van der Valk, Wynstra, \& Axelsson, 2009). Thus, SCM has moved from a dominant focus on flows of goods and information toward an increasing focus on how to 
mobilize and manage capabilities in supply chain relationships.

The focal point in SCM is how to generate value for a specific customer market or firm (Mentzer et al., 2001). Most supply chain research seems to focus on how to plan and manage internal activities and how to coordinate relationships with other supply chain partners (Frankel, Bolumole, Eltantawy, Paulraj, \& Gundlach, 2008). Research in the field seems mainly concerned with running supply chain operations efficiently - doing things right-rather than effectivelydoing the right things.

Our conclusion that creating value in supply chains is related to supply chain effectiveness calls for an examination of the literature on strategic management. The fundamental question in the field of strategic management is how firms achieve competitive advantage to be effective (Teece, Pisano, \& Shuen, 1997). Strategic management focuses on drafting, implementing, and evaluating cross-functional decisions that will enable an organization to achieve its objectives (Hoskisson, Hitt, Wan, \& Yiu, 1999). Traditionally, these objectives are related to firm performance and to how to create value for the firm's customers and shareholders (Sirmon, Hitt, \& Ireland, 2007).

During the past decades, several research streams in strategic management have attempted to explain the mechanisms through which firms create value. We explore in this article which of these research streams discuss how PSM and suppliers contribute to the process of creating and delivering value. PSM's relevance is tied to its capacity to create value. Next, we explore to what extent strategic management concepts are reflected in contemporary academic research in PSM. Both discussions will help us to provide answers to how relevant academic PSM research is and what can be carried out to improve its strategic relevance. In the last sections of this article, we discuss how to improve the rigor of purchasing and supply research. Research on strategically relevant topics has no value if it has not been executed with the highest possible rigor.

\section{ABOUT THE RELEVANCE OF PSM RESEARCH: PSM'S ROLE IN STRATEGIC MANAGEMENT THEORY}

This section describes a number of important developments in the strategic management literature regarding the sources of firm performance. Given the scope of this article, our discussion, also on the implications for PSM, can only be brief. We describe some important contributions in the area of strategic management, which have been categorized into four different eras: (1) strategic planning and marketing theory, (2) competitive strategy, (3) innovation and competence management, and (4) internal and external resource management (see Figure 1).

\section{Strategic Planning and Marketing Theories}

After World War II, American and European industry went through a period of restructuring, recovery, and economic growth. The postwar era was characterized by strong technology development and a growing need for products by consumers. In that period of time, the major concern of entrepreneurs and companies was not so much in how to sell and market products to consumers, because there was a large demand for products. Their major concern was how to secure supply for production in terms of raw materials, components, and parts. Backward integration was a strategy followed to secure basic materials needs (Chandler, 1992). Companies manufactured many parts and components internally. Their intent was to be as self-supporting as they could be. Philips, the Dutchbased manufacturer of consumer lifestyle products, healthcare, and lighting, may serve as an example here. In the early 1960 s, this company had its own glassmanufacturing plants and packaging plants. The company even produced its own toilet seats. Car manufacturers were also highly integrated. General Motors and Ford produced the majority of their parts in-house.

A first sign of strategic change was presented by Ansoff, who introduced his strategic growth matrix (Ansoff, 1957). When pursuing growth, Ansoff presented four different routes: (1) market penetration, (2) product development, (3) market development, and (4) diversification. As a result of this typology, many large American companies embarked particularly on diversification strategies. These strategies were later supported by the PIMS studies, ${ }^{2}$ which were conducted by researchers of Harvard Business School (see for example Schoeffler, Buzzell, \& Heany, 1974). Using both qualitative and quantitative data from over 3,000 business units, a strong correlation between market share and profitability was found. The PIMS studies resulted in more than one hundred publications with a repeated message to entrepreneurs and managers: Build market share so that you can profit from economies of scale (Buzzell, Gale, \& Sultan, 1975). To be profitable, one predominantly should have a number one, two, or three market position. Only these companies would be profitable. Other, smaller companies would suffer. This advice was followed, and as a result, companies started to buy competitors and smaller players to strengthen their market position. Although the research is somewhat outdated, and its results controversial, these market share strategies are still being followed. Heineken, the international beer brewer, and Saint Gobain, the

\footnotetext{
${ }^{2}$ PIMS stands for profit impact of marketing strategies.
} 
FIGURE 1

Business Strategy Concepts Over Time

\begin{tabular}{|c|c|c|c|c|c|c|c|}
\hline \multicolumn{2}{|l|}{ Time/decade } & \multirow{2}{*}{$\begin{array}{l}1960 \\
\text { Strategic planning and } \\
\text { portfolio management }\end{array}$} & \multirow{2}{*}{$\begin{array}{l}1970 \\
\text { Competitive strategy }\end{array}$} & \multirow{2}{*}{$\begin{array}{l}1980 \\
\text { Innovation strategy }\end{array}$} & \multirow{2}{*}{$\begin{array}{l}1990 \\
\text { Resource based strategy }\end{array}$} & \multirow{2}{*}{$\begin{array}{l}2000 \\
\text { Stakeholder strategy }\end{array}$} & \multirow[b]{3}{*}{$\begin{array}{l}\text { Financial } \\
\text { orientation/Share- } \\
\text { holder orientation/ } \\
\text { Firm orientation }\end{array}$} \\
\hline Author & Concepts & & & & & & \\
\hline Ansoff (1957) & $\begin{array}{l}\text { Strategic planning, } \\
\text { product market matrix, } \\
\text { swOT Matrix }\end{array}$ & & & & & & \\
\hline 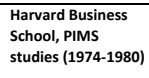 & $\begin{array}{l}\text { Market share leads to } \\
\text { profitability, marketing } \\
\text { focus }\end{array}$ & & & & & & $\square$ \\
\hline $\begin{array}{l}\text { Boston Consulting } \\
\text { Group (1980) }\end{array}$ & $\begin{array}{l}\text { Portfolio manage- } \\
\text { ment, Market } \\
\text { Growth/Market share } \\
\text { matrix }\end{array}$ & & & & & & \\
\hline $\begin{array}{l}\text { Mckinsey, Peters } \\
\text { and Waterman } \\
\text { (1982) }\end{array}$ & $\begin{array}{l}\text { 7S-model: } \\
\text { Superordinate goals, } \\
\text { Strategy, Structure, } \\
\text { Systems, Style, Skills, } \\
\text { Staff }\end{array}$ & & & & & & \\
\hline $\begin{array}{l}\text { Porter, M.E. (1980, } \\
\text { 1985) }\end{array}$ & $\begin{array}{l}\text { Competitive strategy } \\
\text { and value chain } \\
\text { management: three } \\
\text { generic strategies, five } \\
\text { forces model }\end{array}$ & & & & & & \\
\hline $\begin{array}{l}\text { Boston Consulting } \\
\text { Group/Mckinsey } \\
\text { (1990) }\end{array}$ & $\begin{array}{l}\text { Innovation models: } \\
\text { focus on innovation } \\
\text { and 'time-to-market' }\end{array}$ & & & & & & \\
\hline $\begin{array}{l}\text { Barney (1991), } \\
\text { Rumelt (1991), } \\
\text { Wernerfelt (1984) }\end{array}$ & $\begin{array}{l}\text { Competence } \\
\text { management: } \\
\text { managing a bundle of } \\
\text { competences in } \\
\text { parallel }\end{array}$ & & & & & & \\
\hline $\begin{array}{l}\text { Prahalad \& Hamel } \\
\text { (1990), Quinn } \\
\text { (1992) }\end{array}$ & $\begin{array}{l}\text { Competence models: } \\
\text { focus on core } \\
\text { competences, } \\
\text { outsource non core } \\
\text { competences }\end{array}$ & & & & & & \\
\hline $\begin{array}{l}\text { Donaldson \& } \\
\text { Preston (1995), } \\
\text { Freeman et al. } \\
\text { (2007) }\end{array}$ & $\begin{array}{l}\text { Stakeholder theory: } \\
\text { collab. models, } \\
\text { managing int' ' and ext'" } \\
\text { resources in parallel }\end{array}$ & & & & & & $\begin{array}{l}\text { Value orientation/ } \\
\text { Stakeholder orien- } \\
\text { tation/Value Chain } \\
\text { \& Network } \\
\text { Orientation }\end{array}$ \\
\hline
\end{tabular}

French conglomerate in construction materials, may serve as examples here. These companies strive for dominant market shares in all of their markets within three to four years. If they cannot reach that position, they withdraw.

Going for market share was supported by the Boston Consulting Group (BCG), ${ }^{3}$ who introduced their famous market growth-market share matrix. The idea underlying this matrix was to spread financial risks and be selective when investing in new products and markets. Products were categorized into four categories, that is, stars, cash cows, dogs, and question marks. Companies needed to pursue a balanced spread among each of these segments. The stars and cash cows would generate the cash needed to finance the question marks and dogs. The latter should be killed as soon as the situation would allow. ${ }^{4}$

Building market share would allow companies to benefit from the experience curve, which reflected the

${ }^{3}$ See, for example, www.bcgperspectives.com/content/classics/ strategy_the_product_portfolio/

${ }^{4}$ Empirical research (Hambrick, MacMillan, \& Day, 1982) showed that dogs may in fact also produce positive cash flows. practice that, when production volumes would double, the cost per unit would decrease with a certain percentage (Henderson, 1984). BCG demonstrated the experience curve effect for a wide range of products including cars, semiconductors, chemical products, air transport, synthetic fibers, and even insurance. The faster a product enters the market, the sooner a company can benefit from this experience curve effect, capture the financial benefits from it, and invest these in new products and markets. Hence, strategic management theory focused on how to search for growth opportunities and how to select growth markets. Top managers came to see their company as a portfolio of individual business units. Their major challenge was to invest in the most promising product market combinations.

In all of these important contributions to marketing and strategic management ideas, the issue of how to foster or professionalize PSM was absent.

\section{Competitive Strategy}

During the end of the 1970s and the early 1980s, economic growth both in Europe and the U.S. came 
to a halt. Strongly diversified conglomerates appeared to be strategically vulnerable. Strategic management theory had to change. This change was made when Michael Porter entered the strategic management scene. Based upon extensive research in different branches of industry, he took a broader perspective by introducing the value chain concept to explore the competitive position of a company. In exploring a company's value chain, he differentiated between primary activities such as inbound and outbound logistics, operations management, marketing, and after sales services. Next, he identified support activities such as technology development, human resources management, procurement, and infrastructure. Interestingly, he preferred the term procurement over purchasing by arguing that "purchasing, in general, has a too narrow connotation" (Porter, 1985, p.41). Porter was one of the first management theorists who gave explicit attention to PSM and the role of suppliers. In his five forces model, suppliers are one of the five forces, next to direct competitors, new entrants, substitute products, and customers, that determine the attractiveness of an industry.

The importance of Porter's contribution lies primarily in his implicit critique on the former PIMS studies. He demonstrated that excellent profitability was not only related to size. Smaller, specialized and focused companies were also able to generate substantial financial results due to economies of focus. In his view, to be sustainably profitable, companies needed to choose among three generic strategies, that is, cost leadership, product differentiation, and focus. If you did not choose among these three strategies, your profitability would suffer, because you would be "stuck in the middle" (Porter, 1980, p.41).

During the 1980s, product technologies became more complex. One reason was the widespread application of computer technology (IBM's PC was introduced in 1982). For large corporations, it was impossible to finance all growth strategies internally. New competitors, particularly from Japan, entered the field. Later, competitors from these so-called Asian Tigers (including South Korea, Singapore, and Hong Kong) exacerbated the competitive field. These changing competitive circumstances required a change in strategic response. McKinsey introduced its $7 \mathrm{~S}$ model (Peters \& Waterman, 1982), which argued that apart from hard factors such as superordinate goals, strategy, structure, and systems, companies also needed to pay attention to soft factors such as staff, style, and skills. Most of their discussions were limited to processes within the boundaries of the firm. Very little was said about strategies and competences to manage external resources.

Porter introduced procurement as an important driver of competitive performance. However, the discussion on how to position and leverage procurement in business strategy remained very limited in other mainstream (strategic) management literature.

\section{Innovation Strategy and Competence Management}

When discussing competitive strategy in the 1980s, innovation emerged as an important driver of competitive strategy and profitability. International management consultancy firm such as McKinsey and BCG demonstrated through their research a clear relationship between innovation and business profitability. They argued that for a firm, it was important to be first on the market. This would allow the firm to build market share, which was needed to benefit from economies of scale to recoup investments in new product development and be profitable. Being innovative and fast to market became important competitive priorities (Lieberman \& Montgomery, 1988). As a result, management literature on innovation theory and strategy became abundant.

However, when studying the innovative behavior and performance of companies, a major research question was "How is it possible that within one sector some players consistently perform better than their competitors?" The answer came from proponents of the so-called resource-based view of the firm. Here, Rumelt (1991), Wernerfelt (1984), and Barney (1991) provided important contributions and insights. They argued that differences in performance among companies were not primarily to be attributed to the products that they delivered or the market environment in which they operated. Rather, these differences in competitive performance were to be attributed to their resources and the way these resources were actually used. Successful companies seemed able to utilize their resources better and more effectively than their competitors. Resources were to be defined in a broad sense, being both tangible and intangible. Resources included human capital, financial resources, technology, and knowledge. However, the relationships that companies were able to develop with clients, employees, unions, suppliers, and investors were also considered to be important resources. As Wernerfelt (1984) argued, differences in competitive performance resulted from how the combination of resources and relationships was used to solve specific customer problems and needs. Profit was considered not to be an end in itself. However, this was to be considered as a measure for how successfully a company was able to create customer satisfaction. Better solutions and need fulfillment would lead to more satisfied customers, who then were willing to pay a surplus for products and services (Stoelhorst \& Van Raaij, 2004). The adoption of this resource-based view of the firm theory took considerable time (Wernerfelt, 1995). Most 
contributions were limited to specialist academic journals, which prevented business practitioners from getting acquainted with the insights from this school of thought. This situation changed when Prahalad and Hamel (1990) and Quinn (1992) published their ideas on how to shape competitive strategy. These authors argued that companies should differentiate between core versus noncore competencies. They argued that companies should focus on their core competencies, while outsourcing their noncore competencies to suppliers who specialize in these noncore competencies. Through this strategy, the company would become more focused and more flexible to adapt to external uncertainties. As a result, business managers brought their diversification strategies to a halt, investing in core activities and divesting activities that were considered as noncore. Next, internal activities were benchmarked against those of competitors and specialist suppliers. As a result, companies started to outsource important parts of their business processes.

Our observation is that a strategic focus on innovation and, more particularly, competence-based thinking has changed the role of PSM. By the end of the Twentieth Century, the purchasing ratio in (manufacturing) companies had increased to often 60-80 percent of their total cost (Dyer \& Singh, 1998; Monczka et al., 2010; Van Weele, 2010), making companies more dependent on supplier relationships and supplier performance. The PSM function was deemed to be a driver of key purchasing and supply processes and supplier relationships. However, contributions on how to leverage purchasing and supply knowledge and expertise within and across organizations in the mainstream literature remained limited.

\section{From Internal to External Resource Management}

In parallel to the resource-based view of the firm, other researchers have suggested that rather than internal resources, the way firms deal with their external resources determines a firm's competitiveness. Two such theories are the relational view of the firm (Dyer \& Singh, 1998) and resource dependence theory. The central proposition in resource dependence theory, initially proposed by Pfeffer and Salancik (1978), is that firms change as well as negotiate with their external environment to secure access to the resources that they need to survive. Resource dependence theory thereby typically looks beyond the boundaries of an individual firm. It advocates that firms are not selfcontained in fulfilling demands and therefore establish linkages with suppliers to access resources and capabilities required to deliver value (Paulraj \& Chen, 2007). Resource dependence theory implies that suppliers are necessary for adapting to and anticipating the developments in the supply chain's environment.
The relational view posits that both complementary resources controlled by external suppliers and the relationships with such suppliers can be the sources of competitive advantage. Both theories propose that developing effective relationships with the most qualified suppliers is a prerequisite to secure the external resources that are required to create customer value and, hence, foster the firm's competitiveness.

Thus, resource dependence theory and the relational view of the firm complement the resource-based view with external (supplier) resources, competences, and capabilities. Unfortunately, resource dependence theory has not received as much research attention as, for instance, the resource-based view. It is very conceptual in nature and has received scant empirical support (Stock, 2006).

Whereas the resource-based view and resource dependence theory are rather abstract concerning what kind of value needs to be created, stakeholder theory takes account of different value perspectives. Stakeholder theory suggests that each stakeholder represents different values that the focal firm should try to realize (Donaldson \& Preston, 1995; Freeman, 1984; Freeman, Harrison, \& Wicks, 2007). Stakeholder theory criticizes the traditional, primarily financially driven company strategies that were particularly aimed at satisfying shareholder needs and interests. The aim of stakeholder theory is to satisfy a broad array of stakeholder groups based on their specific demands (Harrison, Bosse, \& Phillips, 2010). Creating value for different stakeholders has an effect on the way firms allocate their resources (Freeman et al., 2007). Through stakeholder orientations, firms may create the proper attitudes and behaviors for satisfying their stakeholders and achieving superior firm performance simultaneously (Gatignon \& Xuereb, 1997; Narver \& Slater, 1990). Stakeholder orientations result in firm competitiveness because a focus on stakeholder satisfaction allows a firm to develop trusting relationships with their stakeholders, giving these firms the opportunity to deal better with changes in the environment and consequently spur innovation (Freeman et al., 2007; Harrison et al., 2010). Stakeholders give direction to the external orientations suggested in the resource-based view and resource dependence theory. When we adopt this perspective, suppliers should not only create value for the firm's markets (customers), but also help the buying firm in creating value for society (all stakeholders representing social and environmental concerns) and for those who invested financial resources in the firm (shareholders and investors).

In conclusion, the resource-based view of the firm, resource dependence theory, and stakeholder theory each emphasize a different element of how firms may create value through supply chain orchestration. 
The resource-based view of the firm is more concerned with the management of a firm's internal resources and capabilities that may satisfy external stakeholders of the firm. With resource dependence theory, the firm's dependence on other external parties, such as suppliers, takes central stage. Finally, stakeholder theory focuses on the diverse stakeholder perspectives a firm needs to balance, weigh, and respond to.

Figure 1 provides a schematic overview of how strategic thinking has evolved over time. ${ }^{5}$ We conclude that, over time, strategic management thinking has changed quite dramatically. During the 1960s, creating market share was considered to be the prime concern of management. To increase its profitability, a large market share would enable a company to benefit from economies of scale, and hence cost efficiencies. This idea was challenged by Porter, who demonstrated that specialization could also lead to higher profitability. He introduced the idea of creating a sustainable competitive position through one of three generic strategies, that is, cost leadership, differentiation, or focus. Next, he introduced the concept of the value chain in which procurement was considered to be an important support activity. The relationship with suppliers, in his view, was to be considered as one of the positioning elements. Apart from strategic positioning, innovation became a key issue, as it was demonstrated that companies who are first to market with a new product generate most profits. As a result, the discussion became how to create innovative climate and innovative competencies.

Differences in financial performance among companies were explained by the way in which companies were able to utilize their resources, both internally and externally. Resource management requires that companies focus on what they can do best (i.e., their core competencies) and outsource their noncore activities to specialist suppliers. As a result, the firm can benefit from both focus and supplier specialization. When doing so, relationships with external parties, including suppliers, seem to develop into an important resource, that is, asset. Most discussions in strategic management theory seem to relate to how these resources, that is, assets, can be linked to market and customer strategies and how such effective linkages with outside parties can be created. Strategic management theory reflects an increasingly important role for supply management and supplier resource issues. However, for strategic management scholars, PSM seems not to be considered as a specialist research

\footnotetext{
${ }^{5}$ Please note that the boxes in Figure 1 indicate at roughly what time the respective strategy concepts started to have significant impact on strategic thinking. The concepts generally continue to have impact after that.
}

domain that is able to provide insights into how suppliers can be managed as external resources. In the next section, we will describe how PSM research has evolved over time, and we will discuss differences and similarities of both fields.

\section{TOPICS AND TRENDS IN PAST AND CONTEMPORARY PSM RESEARCH}

What topics have been addressed in PSM research over the past decades? To what extent has PSM research reflected past and contemporary strategic management thinking? For an answer to these questions, we draw on a number of thorough literature surveys. An initial paper providing an overview of PSM doctoral research is the one published by Das and Handfield (1997). Next, Carter and Ellram (2003) provided a critical review of 35 years of 774 papers published in the Journal of Supply Chain Management (JSCM). A third source of information is Wynstra's paper on papers published in the Journal of Purchasing and Supply Management (JPSM) from 1994 to 2009, covering 351 articles (Wynstra, 2010). We also consulted Rozemeijer, Quintens, Wetzels, and Gelderman (2012) for their analysis of the papers submitted to the IPSERA Conference at Maastricht, March 2011. IPSERA represents a large part of the global PSM academic community. Finally, we consulted Spina, Caniato, Luzzini, and Ronchi (2013), who analyzed 1055 articles on PSM published during 2002-2010 in 20 different journals, ranging from (1) PSM-related journals (328 articles) and (2) Marketing and Operations Management journals (526 articles) to (3) General Management and Economics journals (201 articles). As these latter authors integrated the other literature surveys in their analysis, we have taken their research as our point of departure. Another reason is that the scope of their analysis matches our definition of PSM.

The study by Spina et al. (2013) shows that PSM, which for a long time was considered as a subdiscipline of manufacturing and operations management, increasingly gained recognition as a separate discipline over the years, both in research and in practice. As main causes for the latter, the following are mentioned: (1) outsourcing, (2) globalization, and (3) e-business. With regard to the former, the authors argue that PSM has gained a growing recognition among business schools, where the subject, thanks to the growing number of textbooks, is taught both in open enrollment programs and corporate training courses.

For their extensive research of the 1,055 articles, an extended classification framework was used, which enabled the researchers to analyze the database from different angles. Here, we limit our discussion to: unit of analysis, theoretical perspectives, competitive 
priorities, processes, and practices. From 2002 to 2010 the number of papers increased by 163 percent (i.e., from 68 to 179 papers in the journals concerned). Also, the percentage of specific PSM papers relative to the total number of papers increased from 4.7 to 9.6 percent. Papers focusing on the buyer's perspective represented the largest group (421 papers), followed by those focusing on supply networks (347) and dyadic relationships (233). Papers focusing on the supplier perspective represented only a minority (54). In 2010, the topic of supply networks came out as most popular, representing 53.6 percent of the total output.

Looking at the theoretical background of the papers, only 14 percent (146) was grounded in a specific theory (but this percentage rises over the years). The vast majority did not make reference to any theoretical background that was used to inform and structure the research. Of the ones that did, TCE theory was most often used (59), followed by the resource-based view of the firm (27). Resource dependence theory was mentioned 6 times, and stakeholder theory is not among the theories listed by Spina et al. The remaining studies (54) were published using 14 other theoretical perspectives.

Competitive priorities were classified by Spina et al. into cost, innovation, quality, time, sustainability, and flexibility. Of the total of 1,055 papers, 461 addressed such competitive priorities, with the majority (269) focusing on cost; 113 papers were focused on innovation, whereas 110 covered quality as the main research object.

When discussing processes, the following topics were identified: reverse marketing, contract management, supply network configuration, negotiation, vendor rating, supplier management, execution, portfolio management, and requirements definition. Papers appeared to be scattered around these topics, with reverse marketing attracting most papers (137). Only 74 papers were related to contract management, whereas 67 papers had supply network configuration as their primary research focus.

Finally, practices were categorized into the following topics: outsourcing, e-purchasing, local/global, risk management, efficiency, supplier involvement, lean, centralization, cooperative purchasing, and supply base reduction. Here, the focus of most papers was on outsourcing (171) and e-purchasing (127), while the latter 3 topics hardly received any interest.

As stated before, the other authors provided literature reviews based upon a more narrow basis. Most of these were limited to specific PSM journals (or were even limited to one journal such as Carter and Ellram (2003) and Wynstra (2010)). This makes a direct comparison with the findings of Spina et al. (2013) difficult. A direct comparison is also hampered by the different classification frameworks that were used.
Wynstra (2010) found most papers to be related to supply base management/sourcing strategy (45 percent) and supplier relations (25 percent), whereas Carter and Ellram (2003) found most papers to be related to "inventory and production management" and "purchasing organization, teams, and internal relationships." However, these authors observe that since the 1990s, almost all articles reflected a more strategic focus and a broadening and integration of purchasing into supply management and SCM (p. 36). Similar observations are made by Das and Handfield (1997) and Rozemeijer et al. (2012).

What can we conclude based upon this discussion? To what extent are trends and developments in strategic management theory reflected in past and contemporary PSM research? Based upon our discussion, which necessarily can only be brief here, we would conclude that PSM research represents a scattered field that has only limited overlap with strategic management trends and management thinking. Most PSM research seems to lack a clear theoretical underpinning. This hurts, in our view, its identification and recognition outside the PSM community. Of the research that has a theoretical underpinning, most use TCE as main terms of reference, reflecting an economic, cost-oriented view of the firm. PSM research seems only limitedly grounded in the resource-based view of the firm, resource dependence theory, or stakeholder theory.

The interest in foundational theories for supply (chain) management seems to be growing, a process to which the JSCM has been very instrumental. The relevance of the resource-based view for PSM and SCM research has been discussed in a number of recent contributions (Barney, 2012; Hunt \& Davis, 2012; Priem \& Swink, 2012), building in part on contributions made ten years earlier (Mol, 2003; Ramsay, 2001a,b). These important discussions notwithstanding, we observe that little empirical research covers the topics suggested by Ramsay (2001a,b) and Barney (2012). Little PSM research seems to investigate how to develop superior skills, capabilities, and experience of PSM professionals, how to develop and sustain superior codified knowledge of markets and supply chains, how to develop superior power resources over suppliers, how to secure and protect superior procurement competence, and how to build PSM processes within firms that create value, are rare among competitors, are costly to imitate, and have no close substitutes. The interest in foundational theories is growing, and now empirical research needs to follow.

Spina et al.'s (2013) observation that most PSM research seems to be buyer centric and/or dyadic appears to be in contrast with the fact that companies increasingly operate in an interconnected world. To align with the supply chain and network orientation 
(see Figure 1), which is gaining more popularity, supply network centric research seems needed (Gadde, Håkansson, \& Persson, 2010). It is encouraging that this type of research seems to have gained popularity. Competitive priorities seem covered most of the time by research on cost issues. Although we certainly consider this type of research valid, we would argue for more future PSM research on innovation, time, flexibility, and sustainability in supply chain relationships. We observe that PSM research on the last issue is growing rapidly, which may lead to an increased adoption of stakeholder theory in PSM research (Hoejmose \& Adrien-Kirby, 2012).

We argue that grounding future PSM theory in a limited number of established, dominant theories would certainly contribute to a higher visibility and recognition, both academically and in the practitioner field. Such dominant theories preferably should reflect contemporary strategic thinking and current business practices. Network theory, dynamic capabilities theory, stakeholder theory, and the relational view of the firm would most certainly qualify here. Designing future PSM research agendas that align with strategic priorities in the strategic management and business arena would certainly contribute to a broader recognition of the field (Hitt, 2011; Mol, 2003). This would help to improve PSM research relevance. However, this will not prove to be sufficient. To improve PSM research relevance, we also need to address the rigor of contemporary PSM research. We do so in the next section of our paper.

\section{ABOUT THE RIGOR OF FUTURE PSM RESEARCH}

From the reviews of the PSM literature, a picture emerges of increasing attention to theory development (theory building and testing) at the expense of exploration and description (Spina et al., 2013), a finding that is also echoed in the wider operations and SCM field (Singhal \& Singhal, 2012). Concomitant with the aim to test theory, the methodology that is most often used in PSM research is the survey (Spina et al., 2013), even though the (cross-sectional) survey has severe limitations for testing a causal relationship (Dul \& Hak, 2008). The popularity of research strategies may vary between geographies and journals, with the case study being relatively more popular in Europe (Carter \& Ellram, 2003; Wynstra, 2010). Experiments, as a research strategy, represent only a trickle of empirical PSM research publications.

Consistent with the positioning of the JSCM (Carter \& Ellram, 2009), we focus on empirical research methods in this part of our review. Research strategies and research methods for data collection and data analysis should support PSM researchers in developing relevant PSM theories, as discussed in the first part of this review. When we speak about relevance, we do not view rigor and relevance as trade-offs, but we prefer to view methodological rigor in service of research relevance. Management research cannot be truly relevant, if it has not been executed rigorously.

Hence, as a starting point, we do not only subscribe to the notion that "nothing is as practical as a good theory" (Lewin, 1945), but also to the notion that "nothing is as dangerous as a bad theory" (Ghoshal, 2005). Bad theory may lead users of that theory astray, and it may hurt rather than help firm performance. So, what theories should we be looking for to develop the PSM field? We would argue that theory in PSM should be both "relevant" and "robust" (see also Goldsby \& Autry, 2011). Theory in PSM can be deemed relevant if it addresses a phenomenon that directly or indirectly explains performance of an individual, group, organization, or set of organizations in their contemporary context. Theory in PSM can be deemed robust if it is developed based on rigorous methods of research, that is, if it has survived rigorous testing. We reflect upon the relevance, robustness, and rigor of current PSM research looking at three different aspects: research objectives, data collection methods, and data analysis methods. Each aspect is discussed in more detail. Particular concerns are raised. This discussion will help to design a future agenda aimed at enhancing relevance, robustness, and rigor in future PSM research.

\section{Research Objectives}

Individual research projects are generally viewed as being part of a wider process of knowledge creation. This creation process can be described using the empirical cycle, with its five stages of observation, induction, deduction, testing, and evaluation (Van Aken, Berends, \& Van Der Bij, 2012). Research projects may have their prime focus on one or more of these stages. Ideally, PSM research would cover each of these knowledge creation stages in sufficient detail. Does concurrent PSM research do so? Or do some of these stages get more attention than others? These questions may be answered by referring to previous research. Some authors observed a trend in PSM research toward less "observation" and "induction," and more "deduction" and "testing" (Carter \& Ellram, 2003; Singhal \& Singhal, 2012; Spina et al., 2013). Other researchers see this as a sign of PSM becoming a mature field of science (Spina et al., 2013). However, such a situation may create a risk that too few resources are spent on developing new theories. As Carter and Ellram (2003) signaled a decade ago, a need for rigorous, inductive studies continues to exist, 
especially because survey-based theory testing studies tend to provide few breakthrough insights (see also Singhal \& Singhal, 2012).

We add two more observations related to the many theory testing studies that are found in academic PSM journals today. First, many theoretical claims are tested only in a single study, and repeated testing of such claims in different contexts and different times is rare. And second, where there have been multiple tests, there is little evaluation across such tests. Our first observation leads to a call for more replication research, and our second observation to a call for more meta-analytical thinking (see also Goldsby \& Autry, 2011). We explain our views here in more detail.

Many journals, it seems, are preoccupied with newness (Goldsby \& Autry, 2011). Authors are, or at least appear to feel incentivized, to develop and test new relationships and new models in their papers. As we observe, this zest for newness of research findings leads to a multitude of "one-shot studies" in our field (Dul \& Hak, 2008). Practitioners, as well as fellow researchers, are led to believe that a significant effect found in a single study proves the general existence of such an effect in business reality. Very few studies are aimed at replication or verification of findings of previous research.

There seem to be at least three reasons to doubt the validity of a general claim based on a $p$-value found in one single study. First, the significance of a relationship coefficient (in most cases the failure to reject the null hypothesis with a $p<.05$ ) is dependent on chance (Cumming, 2012). Second, the generalizability of the finding may be limited because, unlike in the natural sciences, many parameters in the science of management evolve over time and differ from one population of study units to the next (Singhal \& Singhal, 2012). Third, a finding in one study is often based on less than perfect research methods, such as a nonrandom sampling of study units, a high nonresponse rate (Melnyk, Page, Wu, \& Burns, 2012), and/ or missing data in the data matrix (Tsikriktsis, 2005). Therefore, a theoretical claim based on one single study has to be considered a weak claim (Goldsby \& Autry, 2011). Practitioners who act on such a weak claim are in danger of being led down the wrong path. If journal editors would follow this reasoning, they would need to put far less emphasis on the innovativeness, that is, the newness, of research results as stated in papers that are submitted to them. Rather, they would welcome replication studies or studies aimed at validation of previous studies.

Replication studies would help the PSM field assert whether or not theoretical claims can be generalized to other empirical contexts and/or other timeframes. Next, meta-analytical studies can play an important role in identifying moderating variables, so as to enrich PSM theories. Rigorous testing of PSM theories would require multiple contexts, preferably in combination with longitudinal research designs. These would help the PSM domain to develop meaningful, relevant insights. We feel that in this respect, a lot is to be gained.

\section{Data Collection}

To produce relevant research, specific attention needs to be given to data collection methods. Here we feel that, particularly related to the often-used (selfadministered) questionnaire, it is important to differentiate between respondents and informants. Many PSM phenomena exist at the level of the purchased item, the group (department), the organization, the (dyadic) relationship between organizations, or the network. In all such cases, the person filling out the questionnaire is an "informant," reporting on a phenomenon, external to him or herself. Only in cases where the phenomenon of interest concerns a feeling, opinion, or behavior of the individual involved, is this person to be considered as a true "respondent" (Seidler, 1974). Very often in PSM research, however, this distinction is ignored, and all individuals completing a questionnaire are called "respondents" and are treated as if they are "respondents." We feel that viewing informants as respondents raises particular concerns related to at least three aspects of survey research: sampling, data sources, and measurement.

First of all, there is an implication for sampling, which appears to be often overlooked. There is a logical relation between theoretical domain, population, and sample. Each theory relates to a theoretical domain within which the theoretical claims of that theory are valid. Although the domain is not always explicitly mentioned, one theory may be deemed valid for "purchasing managers in multinational firms," while another theory may be considered valid for "strategic supplier relationships." A theoretical domain is a set of entities to which the theory pertains. Theories are usually meant to be valid for very wide, and hence heterogeneous, domains.

From this domain, the researcher who wishes to test one or more theoretical claims selects a particular population of entities. For example, a researcher may select the Institute for Supply Management (ISM) membership as a population for testing a claim about supply managers. The researcher then takes either a census or a sample from that population (Bonett \& Wright, 2009). The relationships between domain, population, sample, and data set are illustrated in Figure 2. The large solid rectangle represents the theoretical domain. The theory is claimed to be valid for all instances within the domain. The four smaller rectangles with dotted lines represent populations, each 
FIGURE 2

Domain, Population, Sample, and Data Set*

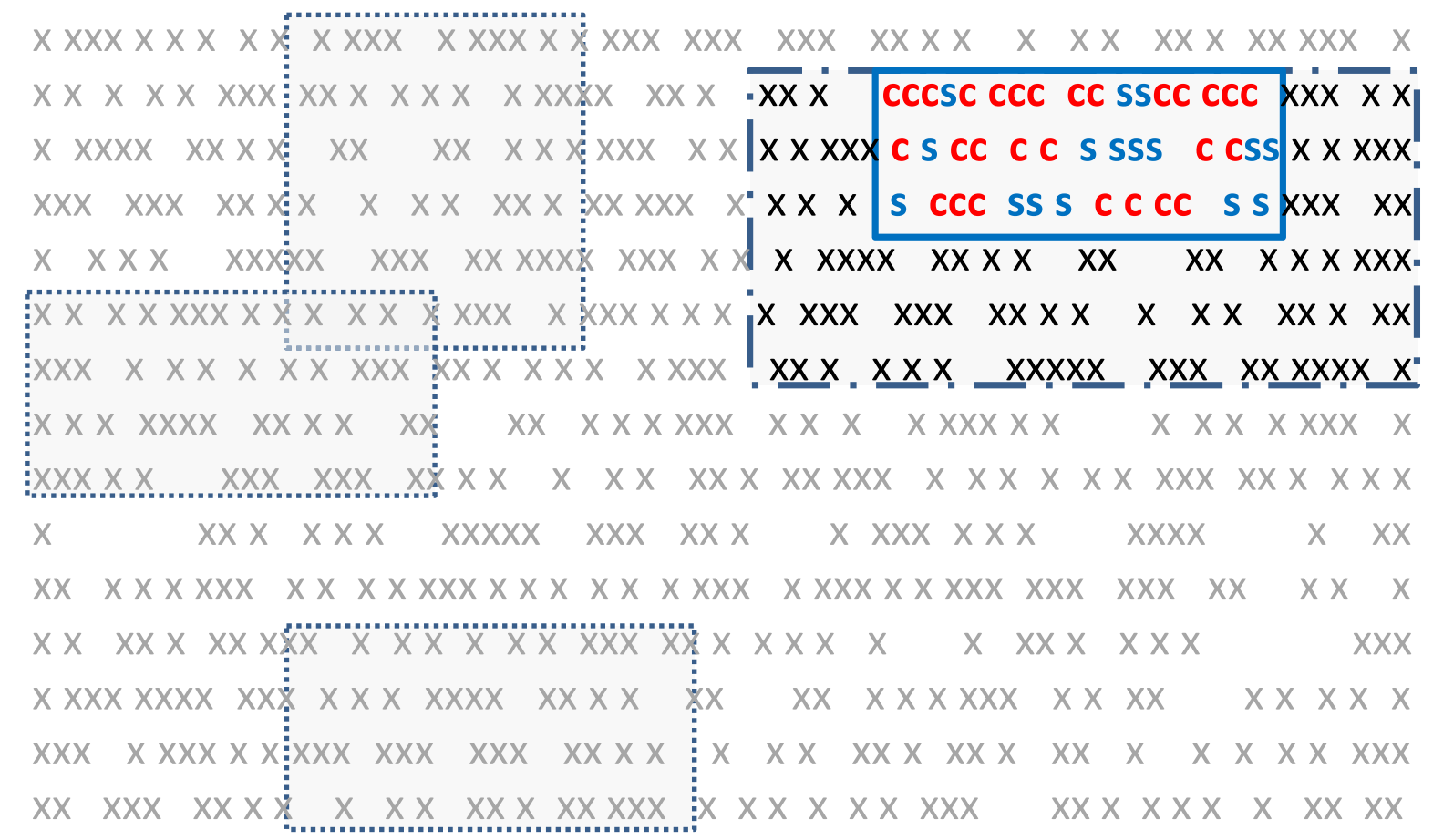

*Based on: Dul and Hak (2008), p. 46

consisting of a subset of instances from the domain (e.g., ISM members being a population within the domain of purchasing and supply managers). The small solid rectangle represents the (probability or nonprobability) sample, chosen by the researcher. The letter " $c$ " denotes a member of the sample who responded and has therefore become one case (or observation) in the data set. The letter "s" denotes a nonresponder from the sample. A one-shot study without replication makes a claim about the whole domain based only on tests among the instances marked as " $\mathrm{c}$ ".

If a study in PSM is a study of anything other than traits of individuals, then it is not individuals that should be sampled. In a study of interorganizational relationships, the researcher needs to sample relationships. In sum, the researcher should first assess to what theoretical domain the theory or theoretical claim that is to be tested pertains. Examples of such domains are "purchasing managers," "strategic items," "captive IT outsourcing centers," and "cross-border sourcing relationships." Only for the first theoretical domain (that of "purchasing managers") could the membership of a purchasing association be chosen as a population to sample respondents from. For the other four examples, the population needs to be defined as, respectively, a population of purchased items, a population of firms, or a population of interfirm relationships. The researcher should sample items, firms, or relationships from the defined population.

Second, the researcher needs to reflect upon the best (combination of) sources to collect valid and reliable data about the entities (units of analysis) that are studied. If the theory operates at the level of the individual, data may well be collected from respondents. Yet, real-life observations, databases, or expert opinions may be even better sources for some research questions. If the theory operates at the level of purchased items, groups, organizations, relationships, or networks, informants may be one among a variety of data sources. Calantone and Vickery (2010) provide various examples of how secondary data can be put to effective and efficient use in PSM and SCM research. Moreover, single informants can only provide very limited insight, when the unit of analysis is a group, a dyadic relationship, or a network. Researchers need to make conscious decisions about what entities are to be sampled and what are the best sources to collect data about those entities, given the theoretical domain 
of the theory they are testing. We would like to challenge the widespread practice of surveying individual PSM professionals as the prime source of information in those cases where the unit of analysis is not the individual.

Third, the ubiquitous approach of surveying individual "respondents" with the use of self-administered questionnaires coincides with a pervasive use of multi-item (reflective) constructs. We observe a routine to consider all variables in research models as unobservable "latent constructs." In discussions with colleagues as well as reviewers, we often are confronted with the opinion that only multi-item constructs constitute valid measurement. This may be due to the fact that much of the measurement theory we use in PSM (and in other OM and SCM research) stems from psychology (from seminal works by for example Nunnaly, 1978; Churchill, 1979; see Gattiker \& Parente, 2007). These theories of measurement are based on the assumption that the researcher is interested in a "respondent" reporting on his or her own feelings, opinions, attitudes, or behaviors, but much of our research in PSM does not concern such latent constructs. The multi-item reflective construct should therefore not be considered the holy grail of measurement. Each variable deserves its own careful consideration of how it is best measured. And the best measure may be a single item (Rossiter, 2002).

Each empirical test of theory should be executed as rigorously as possible, with careful consideration of what entities to sample from which population, what data sources to use to obtain the most valid and reliable data, how to achieve the highest possible response rate if questionnaires are used, and how to measure each variable. These efforts notwithstanding, each empirical test will be an imperfect one, revealing only to what extent the theory holds in the specific population chosen for the study. Multiple rigorous tests of a theoretical claim are needed to build robust theory.

\section{Data Analysis}

Let us spend a few words on data analysis. The current convention in most quantitative, empirical PSM research is to perform null-hypothesis significance testing (NHST). As has been argued by various authors (Bonett \& Wright, 2009; Cumming, 2012; Kirk, 1996; Schwab, Abrahamson, Starbuck, \& Fidler, 2011), NHST provides only a very limited, and sometimes a misguiding, picture of the test outcomes for a theoretical claim. In various other fields of research, such as medicine and psychology, the reporting of effect sizes with confidence intervals, instead of, or in addition to, null-hypothesis significance tests has become the preferred standard. One major flaw of significance tests is that, if samples are expanded, any effect can be made statistically significant. To make our research more rigorous and more relevant, we suggest using effect sizes more prominently when judging PSM and SCM research.

The reporting and interpretation of effect sizes with confidence intervals may help in making better judgments of the practical significance of research outcomes (Kirk, 1996). An obsession with statistical significance (hunting for "asterisks") has made us lose sight of the practical significance of what we have found (Bonett \& Wright, 2009). Effect sizes (with their confidence intervals) should be discussed in terms of what change in the independent variable(s) leads to how much of a change in the dependent variable and with what level of certainty. Such a discussion may reveal that, in spite of statistical significance of the null-hypothesis test, the effort of changing the independent variable(s) will not weigh up to the benefits obtained. And hence, the practical significance of the findings may be limited.

We would argue furthermore that the findings of empirical research should not only be discussed in terms of their practical contribution, but also in terms of the limitations and boundary conditions stemming from the choices made by the researcher. Boundary conditions describe to what extent findings can be generalized to situations other than the one(s) studied. Limitations and boundary conditions should be reported in such a way that readers can understand the consequences of those limitations for the interpretation of results (Brutus, Aguinis, \& Wassmer, 2013). Finally, the findings should be discussed in light of effect sizes found in earlier research (in a meta-analytical sense). Inconsistencies with earlier tests of the same claim(s) may lead to the identification of possible moderating variables to be included in future tests.

\section{REFLECTIONS: HOW TO MAKE FUTURE PSM RESEARCH MORE RELEVANT AND ROBUST}

We conclude that research in PSM has developed considerably during the last decades, both in terms of quantity and in terms of quality. Over time, the number of articles, both in PSM-specific journals and in marketing and operations management and general management journals, has grown, covering about 10 percent of all articles published. Past and contemporary PSM research is related to a wide range of topics, that are addressed by a wide range of methodologies. Of these, deductive, theory testing, quantitative and survey-based methodologies have gained increasing popularity, at the cost of inductive, theory building, qualitative, case-based methodologies. In terms of quality, PSM research has made inroads both in PSM-specific and other academic journals. During the past years, both JSCM and JPSM gained 
academic accreditation through their ISI citation ratings. We conclude that the PSM academic community over the past years has been quite active and successful.

However, when addressing the effectiveness of future PSM research, we have articulated some ideas on how to foster its relevance and rigor. As we have argued, PSM has adopted a more strategic role in organizations due to outsourcing, globalization, and information technology. As a result, companies have become much more interconnected. This is reflected in strategic management theory where corporate planning, portfolio management, and competitive strategy, favoring a single, financially driven shareholder view, gradually have made room for value driven, multistakeholder resource-based strategies. As a result, value-based management, network theory, stakeholder theory, and resource and competence management have gained more popularity. Whether PSM is strategic depends on its ability to develop superior PSM skills, capabilities, and experience of PSM professionals, to develop and sustain superior codified knowledge of markets and supply chains, to develop superior power resources over suppliers, and to secure and protect superior procurement competence. Contemporary PSM research seems to reflect these strategic priorities only to a limited extent. To improve both its recognition in adjacent academic domains and its relevance to practitioners, we feel that PSM researchers should initiate much more research in these areas, that is, address much more of these topics in the future. When doing so, future research should be better embedded and grounded in management, economic, and social theories. Here, we would propose stakeholder theory, network theory, the resourcebased view of the firm, dynamic capabilities theory, and the relational view as potential candidates. We would rather see future research embedded in less, but more prominent, dominant, and relevant theories than to continue with the current PSM research landscape. Rigor and relevance of academic research are interconnected.

We see many ways in which our research methods in the field of PSM (as well as SCM) can improve and lead to higher relevance, rigor, and robustness of our theoretical claims. To complete this message, we would like to provide a few recommendations to the editors of the JSCM and other journals of our field. First, we would support an increase in the number of replication studies as a key element in the development of robust and relevant theories. Next, we would support the idea of encouraging researchers to publish meta-analytical studies. Of course, this would require reviewers to develop expertise in the areas of replication studies and meta-analyses. In line with the foregoing, we would suggest that authors position their research more explicitly amid earlier studies and discuss their theory tests in a meta-analytical way: How does this new test complement and/or refine earlier tests of the same proposition(s)? When discussing results of quantitative studies, we would further suggest that authors report on effect sizes and confidence intervals, rather than $p$-values, which would enable them to better discuss the practitioner relevance and implications of their research.

With these recommendations and ideas, we hope to contribute to a wider recognition and acceptance of future PSM research. Of course, with these ideas we not only address editors and reviewers of academic journals. These ideas represent concomitant implications for all of us in the field: for what we submit as authors to our journals and what we review as reviewers.

We congratulate JSCM, its editors, reviewers, and authors with the Journal's 50th anniversary. This is quite a landmark. During its lifetime, JSCM, through its activities, has contributed greatly to the academic and practitioner world. However, there is no time for complacency as our community, with JSCM and other journals, consistently and relentlessly needs to improve on our relevance and rigor. This was, is, and will be our perpetual challenge and mission!

\section{REFERENCES}

Anderson, J. C., Thomson, J. B. L., \& Wynstra, F. (2000). Combining value and price to make purchase decisions in business markets. International Journal of Research in Marketing, 17 (4), 307-329.

Ansoff, H. I. (1957). Strategies for diversification. Harvard Business Review, 35 (5), 113-124.

Barney, J. (1991). Firm resources and sustained competitive advantage. Journal of Management, 17 (1), 99-120.

Barney, J. B. (2012). Purchasing, supply chain management and sustained competitive advantage: The relevance of resource-based theory. Journal of Supply Chain Management, 48 (2), 3-6.

Bonett, D. G., \& Wright, T. A. (2009). Using confidence intervals in supply chain and operations research. Journal of Supply Chain Management, 45, 26-33.

Brutus, S., Aguinis, H., \& Wassmer, U. (2013). Selfreported limitations and future directions in scholarly reports: Analysis and recommendations. Journal of Management, 39, 48-75.

Buzzell, R. D., Gale, B. T., \& Sultan, R. G. M. (1975). Market share: A key to profitability. Harvard Business Review, 53 (1), 97-106.

Calantone, R. J., \& Vickery, S. K. (2010). Introduction to the special topic forum: Using archival and secondary data sources in supply chain management research. Journal of Supply Chain Management, 46 (4), 3-11. 
Carr, A. S., \& Pearson, J. N. (1999). Strategically managed buyer-supplier relationships and performance outcomes. Journal of Operations Management, 17, 497-519.

Carter, P. L., Carter, J. R., Monczka, R. M., Slaight, T. H., \& Swan, A. J. (2000). The future of purchasing and supply: A ten-year forecast. Journal of Supply Chain Management, 36, 14-26.

Carter, C. R., \& Ellram, L. M. (2003). Thirty-five years of the Journal of Supply Chain Management: Where have we been and where are we going? Journal of Supply Chain Management, 39 (2), 27-39.

Carter, C. R., \& Ellram, L. M. (2009). The 45th anniversary of the journal of supply chain management: Progress to date and continued excellence moving forward. Journal of Supply Chain Management, 45, 5-7.

Chandler, A. D. (1992). Organizational capabilities and the economic history of the industrial enterprise. The Journal of Economic Perspectives, 6 (3), 79-100.

Chen, I. J., \& Paulraj, A. (2004). Towards a theory of supply chain management: The constructs and measurements. Journal of Operations Management, 22, 119-150.

Chen, I. J., Paulraj, A., \& Lado, A. A. (2004). Strategic purchasing, supply management, and firm performance. Journal of Operations Management, 22, 505-523.

Choi, T. Y., Wu, Z., Ellram, L., \& Koka, B. R. (2002). Supplier-supplier relationships and their implications for buyer-supplier relationships. Engineering Management, IEEE Transactions on, 49, 119-130.

Churchill, G. A. (1979). A paradigm for developing better measures of marketing constructs. Journal of Marketing Research, 16, 64-73.

Cumming, G. (2012). Understanding the new statistics: Effect sizes, confidence intervals, and meta-analysis. New York: Routledge.

Das, A., \& Handfield, R. B. (1997). A meta-analysis of doctoral dissertations in purchasing. Journal of Operations Management, 15 (2), 101-121.

Donaldson, T., \& Preston, L. E. (1995). The stakeholder theory of the corporation: Concepts, evidence, and implications. Academy of Management Review, 20 (1), 65-91.

Dul, J., \& Hak, T. (2008). Case study methodology in business research. New York: Routledge.

Dyer, J. H., \& Singh, H. (1998). The relational view: Cooperative strategy and sources of interorganizational competitive advantage. Academy of Management Review, 23 (4), 660-679.

Ellram, L. M., \& Carr, A. (1994). Strategic purchasing: A history and review of the literature. International Journal of Purchasing and Materials Management, 30 (2), 10-18.

Ellram, L. M., Tate, W. L., \& Billington, C. (2004). Understanding and managing the services supply chain. Journal of Supply Chain Management, 40 (4), 17-32.
Frankel, R., Bolumole, Y. A., Eltantawy, R. A., Paulraj, A., \& Gundlach, G. (2008). The domain and scope of SCM's foundational disciplines-Insights and issues to advance research. Journal of Business Logistics, 29, 1-30.

Freeman, R. E. (1984). Strategic management: A stakeholder approach. Englewood Cliffs, NJ: Prentice Hall.

Freeman, R. E., Harrison, J. S., \& Wicks, A. C. (2007). Managing for stakeholders: Survival, reputation, and success. New Haven, CT: Yale University Press.

Gadde, L. E., \& Håkansson, H. (1994). The changing role of purchasing: Reconsidering three strategic issues. European Journal of Purchasing \& Supply Management, 1, 27-35.

Gadde, L. E., Håkansson, H., \& Persson, G. (2010). Supply network strategies. (2nd ed.) New York: Wiley.

Gatignon, H., \& Xuereb, J. M. (1997). Strategic orientation of the firm new product performance. Journal of Marketing Research, 34, 77-90.

Gattiker, T. F., \& Parente, D. H. (2007). Introduction to the special issue on innovative data sources for empirically building and validating theories in operations management. Journal of Operations Management, 25 (5), 957-961.

Gelderman, C. J. (2003). A portfolio approach to the development of differentiated purchasing strategies. PhD thesis, Eindhoven, the Netherlands: Eindhoven University of Technology.

Ghoshal, S. (2005). Bad management theories are destroying good management practices. Academy of Management Learning \& Education, 4, 75-91.

Giunipero, L. C., Hooker, R. E., Joseph-Matthews, S., Yoon, T. E., \& Brudvig, S. (2008). A decade of SCM literature: Past, present and future implications. Journal of Supply Chain Management, 44 (4), 66-86.

Goldsby, T. J., \& Autry, C. W. (2011). Toward greater validation of supply chain management theory and concepts: The roles of research replication and meta-analysis. Journal of Business Logistics, 32, 324-331.

González-Benito, J. (2007). A theory of purchasing's contribution to business performance. Journal of Operations Management, 25 (4), 901-917.

Hambrick, D. C., MacMillan, I. C., \& Day, D. L. (1982). Strategic attributes and performance in the BCG matrix-A PIMS-based analysis of industrial product businesses. Academy of Management Journal, 25 (3), 510-531.

Harrison, J. S., Bosse, D. A., \& Phillips, R. A. (2010). Managing for stakeholders, stakeholder utility functions, and competitive advantage. Strategic Management Journal, 31, 58-74.

Henderson, B. D. (1984). The application and misapplication of the experience curve. Journal of Business Strategy, 4 (3), 3-9.

Hitt, M. A. (2011). Relevance of strategic management theory and research for supply chain management. Journal of Supply Chain Management, 47, $9-13$. 
Hoejmose, S. U., \& Adrien-Kirby, A. J. (2012). Socially and environmentally responsible procurement: A literature review and future research agenda of a managerial issue in the 21st century. Journal of Purchasing and Supply Management, 18 (4), 232-242.

Holmen, E., Pedersen, A. C., \& Jansen, N. (2007). Supply network initiatives-a means to reorganise the supply base? Journal of Business \& Industrial Marketing, 22 (3), 178-186.

Hoskisson, R. E., Hitt, M. A., Wan, W. P., \& Yiu, D. (1999). Theory and research in strategic management: Swings of a pendulum. Journal of Management, 25 (3), 417-456.

Hunt, S. D., \& Davis, D. F. (2012). Grounding supply chain management in resource-advantage theory: In defense of a resource-based view of the firm. Journal of Supply Chain Management, 48 (2), 14-20.

Joshi, A. W. (2009). Continuous supplier performance improvement: Effects of collaborative communication and control. Journal of Marketing, 73 (1), 133-150.

Kibbeling, M. I. (2010). Creating Value in Supply Chains: Supplier's Impact on Value for Customers, Society and Shareholders. PhD thesis, Eindhoven, the Netherlands: Eindhoven University of Technology.

Kirk, R. E. (1996). Practical significance: A concept whose time has come. Educational and Psychological Measurement, 56 (5), 746-759.

Kouvelis, P., Chambers, C., \& Wang, H. (2006). Supply chain management research and production and operations management: Review, trends, and opportunities. Production and Operations Management, 15 (3), 449-469.

Kraljic, P. (1983). Purchasing must become supply management. Harvard Business Review, 61 (5), 109-117.

Lee, H. L., Padmanabhan, V., \& Whang, S. (1997). Information distortion in a supply chain: The bullwhip effect. Management Science, 43 (4), 546-558.

Leenders, M. R., \& Fearon, H. E. (2008). Developing Purchasing's Foundation. Journal of Supply Chain Management, 44 (2), 17-27.

Lewin, K. (1945). The research center for group dynamics at Massachusetts Institute of Technology. Sociometry, 8, 126-136.

Lieberman, M. B., \& Montgomery, D. B. (1988). Firstmover advantages. Strategic Management Journal, 9 (S1), 41-58.

Melnyk, S. A., Page, T. J., Wu, S. J., \& Burns, L. A. (2012). Would you mind completing this survey: Assessing the state of survey research in supply chain management. Journal of Purchasing and Supply Management, 18, 35-45.

Mentzer, J. T., DeWitt, W., Keebler, J. S., Min, S., Nix, N. W., \& Smith, C. D. (2001). Defining supply chain management. Journal of Business Logistics, 22 (2), 1-25.
Mentzer, J. T., Min, S., \& Zacharia, Z. G. (2000). The nature of interfirm partnering in supply chain management. Journal of Retailing, 76 (4), 549-568.

Mol, M. (2003). Purchasing's strategic relevance. Journal of Purchasing \& Supply Management, 9, 43-50.

Monczka, R. M., Handfield, R. B., Guinipero, L. C., Patterson, J. L., \& Waters, D. (2010) Purchasing \& supply chain management. London: Cengage Learning.

Narver, J. C., \& Slater, S. F. (1990). The effect of a market orientation on business profitability. Journal of Marketing, 54 (4), 20-35.

Nunnaly, J. (1978). Psychometric Theory. (2nd ed.) New York: McGraw-Hill.

Ogden, J. A., Petersen, K. J., Carter, J. R., \& Monczka, R. M. (2005). Supply management strategies for the future: A delphi study. Journal of Supply Chain Management, 41 (3), 29-48.

Paulraj, A., \& Chen, I. J. (2007). Environmental uncertainty and strategic supply management: A resource dependence perspective and performance implications. Journal of Supply Chain Management, 43 (3), 29-42.

Peters, T., \& Waterman, R. H. (1982). In search of excellence. New York: The Free Press.

Pfeffer, J., \& Salancik, G. R. (1978). The external control of organizations: A resource dependence perspective. New York: Harper and Row.

Porter, M. E. (1980). Competitive strategy. New York: The Free Press.

Porter, M. E. (1985). Competitive advantage. New York: The Free Press.

Porter, M. E., \& Kramer, M. R. (2006). Strategy \& society: The link between competitive advantage and corporate social responsibility. Harvard Business Review, 84 (12), 78-92.

Prahalad, C. K., \& Hamel, G. (1990). The core competence of the corporation. Harvard Business Review, 68 (4), 79-91.

Priem, R. L., \& Swink, M. (2012). A demand-side perspective on supply chain management. Journal of Supply Chain Management, 48 (2), 7-13.

Quinn, J. B. (1992), Intelligent enterprise (p. 473). New York: The Free Press.

Ramsay, J. (2001a). Purchasing's strategic irrelevance. European Journal of Purchasing \& Supply Management, 7 (4), 257-263.

Ramsay, J. (2001b). The resource based perspective, rents, and purchasing's contribution to sustainable competitive advantage. Journal of Supply Chain Management, 37 (3), 38-47.

Rosenzweig, E. D., \& Roth, A. V. (2007). B2B seller competence: Construct development and measurement using a supply chain strategy lens. Journal of Operations Management, 25 (6), 1311-1331.

Rossiter, J. R. (2002). The C-OAR-SE procedure for scale development in marketing. International journal of research in marketing, 19, 305-335. 
Rozemeijer, F., Quintens, L., Wetzels, M., \& Gelderman, C. (2012). Vision 20/20: Preparing today for tomorrow's challenges. Journal of Purchasing and Supply Management, 18 (2), 63-67.

Rumelt, R. P. (1991). How much does industry matter? Strategic Management Journal, 12 (3), $167-185$.

Sampson, S. E., \& Spring, M. (2012). Service supply chains: Introducing the special topic forum. Journal of Supply Chain Management, 48 (4), 3-7.

Schoeffler, S., Buzzell, R., \& Heany, D. (1974). Impact of strategic planning on profit performance. Harvard Business Review, 52, 137-145.

Schoenherr, T., Modi, S. B., Benton, W. C., Carter, C. R., Choi, T. Y., Larson, P. D., Wagner, S. M. (2012). Research opportunities in purchasing and supply management. International Journal of Production Research, 50 (16), 4556-4579.

Schwab, A., Abrahamson, E., Starbuck, W. H., \& Fidler, F. (2011). Perspective-Researchers should make thoughtful assessments instead of nullhypothesis significance tests. Organization Science, 22 (4), 1105-1120.

Seidler, J. (1974). On using informants: A technique for collecting quantitative data and controlling measurement error in organization analysis. American Sociological Review, 39 (6), 816-831.

Singhal, K., \& Singhal, J. (2012). Opportunities for developing the science of operations and supplychain management. Journal of Operations Management, 30, 245-252.

Sirmon, D. G., Hitt, M. A., \& Ireland, R. D. (2007). Managing firm resources in dynamic environments to create value: Looking inside the black box. Academy of Management Review, 32 (1), 273-292.

Spekman, R. E., \& Carraway, R. (2006). Making the transition to collaborative buyer-seller relationships: An emerging framework. Industrial Marketing Management, 35, 10-19.

Spina, G., Caniato, F., Luzzini, D., \& Ronchi, S. (2013). Past, present and future trends of purchasing and supply management: An extensive literature review. Industrial Marketing Management, in press. doi:10. 1016/j.indmarman.2013.04.001

Stock, R. M. (2006). Interorganizational teams as boundary spanners between supplier and customer companies. Journal of the Academy of Marketing Science, 34 (4), 588-599.

Stoelhorst, J. W., \& Van Raaij, E. M. (2004). On explaining performance differentials: Marketing and the managerial theory of the firm. Journal of Business Research, 57, 462-477.

Teece, D. J., Pisano, G., \& Shuen, A. (1997). Dynamic capabilities and strategic management. Strategic Management Journal, 18 (7), 509-533.

Trent, R. J., \& Monczka, R. M. (1998). Purchasing and supply management: Trends and changes throughout the 1990s. Journal of Supply Chain Management, 34 (4), 2-11.
Tsikriktsis, N. (2005). A review of techniques for treating missing data in OM survey research. Journal of Operations Management, 24, 53-62.

Van Aken, J., Berends, H., \& Van Der Bij, H. (2012). Problem solving in organizations: A methodological handbook for business and management students. Cambridge, UK: Cambridge University Press.

Van der Valk, W., Wynstra, F., \& Axelsson, B. (2009). Effective buyer-supplier interaction patterns in ongoing service exchange. International Journal of Operations \& Production Management, 29, 807-833.

Van Echtelt, F. (2004). New product development: Shifting suppliers into gear. PhD thesis, Eindhoven, the Netherlands: Eindhoven University of Technology.

Van Weele, A. J. (2010). Purchasing and supply chain management: Analysis, strategy, planning and practice. (5th ed.) London: Cengage Learning.

Wernerfelt, B. (1984). A resource-based view of the firm. Strategic Management Journal, 5, 171-180.

Wernerfelt, B. (1995). The resource-based view of the firm: Ten years after. Strategic Management Journal, 16 (3), 171-174.

Williamson, O. E. (1981). The economics of organization: The transaction cost approach. American Journal of Sociology, 87 (3), 548-577.

Williamson, O. E. (1991). Comparative economic organization: The analysis of discrete. Administrative Science Quarterly, 36, 269-296.

Wolf, H. H. (2005). Making the transition to strategic purchasing. MIT Sloan Management Review, 46 (4), 17-20.

Wynstra, F. (1998). Purchasing involvement in product development. PhD thesis, Eindhoven, the Netherlands: Eindhoven University of Technology.

Wynstra, F. (2010). What did we do, who did it and did it matter? A review of fifteen volumes of the (European) Journal of Purchasing and Supply Management. Journal of Purchasing and Supply Management, 16 (4), 279-292.

Arjan J. van Weele (Ph.D., Eindhoven University of Technology) holds the NEVI Chair in Purchasing and Supply Management at the School of Industrial Engineering at Eindhoven University of Technology, the Netherlands. Dr. Van Weele's research interests lie in managing upstream global value chains, where companies have to rely on interorganizational networks and have to deal with interorganizational conflict of interests. In this respect, international contracting and contract management are subjects of ongoing research. Dr. Van Weele is the author of several leading textbooks in the field including "Purchasing and Supply Chain Management," which has been published in several languages. His articles have been published in 
among others the Journal of Supply Chain Management (JSCM), Journal of Purchasing and Supply Management, Industrial Marketing Management, Journal of Product Innovation Management and European Management Journal. Dr. Van Weele has been a consultant to many large European companies, including Skanska, Heineken, Philips and Shell, and serves on the supervisory board of a few midsize companies. He is a member of the Advisory Board of the JSCM and the Journal of Purchasing and Supply Management.

Erik M. van Raaij (Ph.D., University of Twente) is an associate professor of purchasing and supply management in the Rotterdam School of Management at
Erasmus University, Rotterdam, the Netherlands. His research interests include healthcare procurement, buyer-supplier relationships, socially responsible purchasing, research methods, and research ethics. Dr. Van Raaij has published in journals such as Organization Science, Journal of Management Studies, Journal of Business Ethics, California Management Review, and the International Journal of Production Research, and he is an associate editor for the Journal of Purchasing and Supply Management. 